\title{
Çocuk Yoğun Bakımda Diyare ilişkili Hemolitik Üremik Sendrom: Tek Merkez Deneyimi
}

\section{Single Center Experience of Diarrhea Associated Hemolytic Uremic Syndrome in Pediatric Intensive Care Unit}

\author{
Caner Alparslan ${ }^{1}$ (D), Mehmet Nur Talay² (D), Aysel Taktak ${ }^{3}$, Murat Kanğın² (D)
}

\author{
${ }^{1}$ Sağlık Bilimleri Üniversitesi İzmir Tepecik Eğitim ve Araştırma Hastanesi, Çocuk Nefrolojisi Kliniği, İzmir, Türkiye \\ ${ }^{2}$ Sağılı Bilimleri Üniversitesi Diyarbakır Gazi Yaşargil Eğitim ve Araştırma Hastanesi, Çocuk Yoğun Bakım Kliniği, Diyarbakır, Türkiye \\ ${ }^{3}$ Hatay Mustafa Kemal Üniversitesi, Çocuk Nefrolojisi Bilim Dalı, Hatay, Türkiye
}

ORCID ID: C.A. 0000-0002-7046-8907; M.N.T. 0000-0002-7361-3823; A.T. 0000-0001-7724-9160; M.K. 0000-0003-0042-0569

Attf/Citation: Alparslan C, Talay MN, Taktak A, Kangin M. Çocuk Yoğun bakımda diyare ilişkili hemolitik üremik sendrom: Tek merkez deneyimi. Çocuk Dergisi - Journal of Child 2021;21(1):13-20. https://doi.org/10.26650/jchild.2021.1.860634

öz

Amaç: Hemolitik üremik sendrom, akut böbrek hasarı, hemolitik anemi ve trombositopeni ile karakterizedir. Çocuklarda en sık diyare ilişkili HÜS (D+ HÜS) olarak görülmektedir. Bu çalışmada amaç D+HÜS klinik parametrelerinin ve hastalığın sonlanımı açııından öngördürücülerin belirlenmesidir. Gereç ve Yöntem: Geriye dönük olarak yapılan bu çalışmaya Mart 2019 Ağustos 2020 tarihleri arasında çocuk yoğun bakımda D+HÜS tanısı alan 15 hasta dahil edildi. Olguların demografik özellikleri, başvuru yaşamsal bulguları, laboratuvar parametreleri (hemoglobin, hemotokrit, beyaz kan hücresi, trombosit, kreatinin, üre, ürik asit, laktat dehidrogenaz, aspartat aminotransferaz, alanin aminotransferaz, amilaz, albümin, C3 ve C4), plazma tedavisi, plazma değişimi, böbrek yerine koyma tedavisi (BYKT) uygulandıysa tipi ve süresi, kan ürünü ihtiyacı olup olmadığı incelendi. Ayrıca olgularda böbrek dışında organ tutulumu varlığı, eculizumab tedavisi kullanımı ve izlemde son durumları kayıt altına alındı.

Bulgular: Çalışma grubunun 9'u (\%60) erkek olup, yaş ortalaması ortanca 18 ay olarak hesaplandı. Tüm çalışma grubunun $\% 60^{\prime}$ ında BYKT ihtiyacı olup, periton diyalizinin [5 $(\% 33,3)]$ en sık tercih edilen yöntem olduğu görüldü. Beş olguda $(\% 33,3)$ böbrek dışı organ tutulumu izlendi. Taburculuk sonrası izlem süresince (ort:9,59 $\pm 6,03$ ay), 9 (\%60)'unun normale döndüğü, 3 (\%20)'ünün proteinüri, $1(\% 6,6)$ 'inde kronik böbrek hastalığı, 1 $(\% 6,6)$ 'inde son dönem böbrek yetmezliği ve $1(\% 6,6)$ 'inde de nörolojik sekel kaldığı görüldü. Hastane yatış ve oligoanüri süresinin sekel gelişimi üzerine istatistiksel olarak anlamlı etkisi olduğu görüldü [Hastane yatış süre: OR:1,28 (\%95 Cl:0,77-0,98) ( $p=0,04)$, Oligoanüri süre: OR:1,46 (\%95 $\mathrm{Cl}: 0,94-1)(p=0,04)]$.

Sonuç: Bu çalışmada hastane yatış ve oligoanüri süresinin sekel gelişimi üzerine anlamlı etkisi gösterildi. Bu hastalığın daha iyi tanınarak yönetiminin geliştirilmesi ile bu kötü sonuçların azaltılabilmesi için daha çok klinik çalışmaya ihtiyaç olduğunu düşünmekteyiz.

Anahtar Kelimeler: Çocuk, hemolitik üremik sendrom, diyare, yoğun bakım

\section{ABSTRACT}

Objective: Hemolytic uremic syndrome (HUS) is characterised by acute kidney injury, hemolytic anemia and thrombocytopenia. In children, it is mostly related with diarrhea $(\mathrm{D}+)$. In this paper, we aimed to determine clinical parameters and prognostic factors in D+HUS.

Materials and Methods: This retrospective study was conducted with D+HUS 15 pediatric patients in a pediatric intensive care unit between March 2019 and August 2020. Patients demographics, initial vital signs, laboratory parameters (hemoglobine, hematocrit, white blood cell, platellets, creatinine, urea, uric acid, lactat dehydrogenase, aspartat aminotransferase, alanine aminotransferase, amilase, albumine, C3 and C4), plasma therapy, plasma exchange, RRT type and duration, and the need for blood products were evaluated. Therefore, extra-renal involvement, eculizumab treatment and last follow-up were recorded. Results: The study group consisted of 9 males $(60 \%)$ and the median age was calculated as 18 months. In $60 \%$ of the patients, RRT was implemented. Peritoneal dialysis (in 5) was the most preferded dialysis method. Five patients (33\%) had extra-renal involvement. Nine patients $(60 \%)$ had completely recovered, therefore proteinuria, chronic kidney disease, endstage kidney disease and neurologic sequel developed in $3(20 \%), 1$ (6.6\%), $1(6.6 \%)$ and $1(6.6 \%)$, respectively. Hospitalization and oligoanuria duration had a significant impact on sequel development [Hospitalization duration: OR:1.28 (\%95 Cl:0.77-0.98) ( $p=0.04)$, Oligoanuria duration: OR:1.46 (\%95 Cl:0.94-1) ( $p=0.04)]$.

Conclusion: In this study, we showed that hospitalization and oligoanuria duration had a significant impact on sequel development. We believe that there is a need for more clinical studies to delinate more precise mechanisms of the disease and eliminate worse outcomes of D+HUS.

Keywords: Child, hemolytic uremic syndrome, diarrhea, intensive care unit

Sorumlu Yazar/Corresponding Author: Caner Alparslan E-mail: caneralparslan@gmail.com

Başvuru/Submitted: 08.09.2020 • Revizyon Talebi/Revision Requested: 04.02.2021 • Son Revizyon/Last Revision Received: 04.01.2021 • Kabul/Accepted: 22.02 .2021 


\section{GíRiş}

Çocukluk çağında akut böbrek hasarının önemli nedenlerinden birisi olan hemolitik üremik sendrom (HÜS), akut böbrek hasarı, immünolojik olmayan hemolitik anemi ve trombositopeni ile karakterizedir $(1,2)$. Trombotik mikroanjiyopatik hastalıklar içerisinde yer almakta olan bu nadir fakat ciddi sendrom çocuklarda en sık diyare ilişkili HÜS ( $D+H U ̈ S$ ) olarak görülmektedir $(2,3)$. Hastaların büyük çoğunluğunun 5 yaş altında görüldügü ve görülme oranlarının ülkeler arasında farklılıklar içerdiği bildirilmektedir (3-6). Beş yaş alt D+HÜS sıklığında en yüksek oran Latin Amerika ülkesi olan Arjantin'den bildirilmiş olup (17/100.000 nüfus), bu sıklık Avrupa'da 0.6-0.8/100.000 nüfus, Amerika Birleşik Devletleri'nde ise 1,9-2,9/100.000 nüfus olarak ifade edilmektedir (3).

Diyare ilişkili hemolitik üremik sendrom, vakaların \%90'ını teşkil etmekte olup, bunların büyük kısmından şiga toksin üreten E.coli 0157:H7 suşu sorumludur (3-9). 2010 yılından sonra diğer suşlar da (O26:H11, O145:H28, O103:H2, O111:H8, O104:H4) artan sıklıklarda bildirilmektedir $(3,4,9)$. Şiga toksin üreten E.coli kaynaklı enteritlerin sonrasında \%10-15 oranında HÜS gelişmektedir (3,4,7,9-11). Hemolitik üremik sendrom sıklıkla enterit sonrasındaki 7-14 gün içerisinde gelişmektedir. Olguların \%60-70 kadarında kanlı ishal görülmektedir (12). Bu hastalarda HÜS gelişmesi için risk faktörleri, 5 yaşın altında olmak, kusma, 3 günden uzun süren diyare, kanlı dışkılama ve beyaz kan hücre sayısının 13.000/ml'den yüksek olması olarak tanımlanmakta$\operatorname{dır}(1,3,6,9,12)$. Hastalığa özgü bir tedavisi bulunmayan D+HÜS tablosunda hastalar destek tedavileri ile izlenmektedir $(2,3,6)$. Ancak hastaların 2/3'ünde böbrek yerine koyma tedavisi (BYKT) ihtiyacı gelişmektedir $(4,10)$. Ayrıca $\% 20$ oranda böbrek dışı organ tutulumları da görülebilmektedir. Bu tutulumlar nörolojik (ensefalopati, nöbet, koma, hemiparezi, kortikal körlük), gastrointestinal sistem (barsak nekrozu, perforasyon, striktür ve pankreatit), kardiyak (iskemi ve artan kardiyak enzim düzeyi, kardiyak yetmezlik), endokrinolojik (diyabet mellitus) ve kasiskelet sistemi (rabdomiyoliz) şeklinde meydana gelebilmektedir (4). Hastaların \%70'i tam olarak iyileşmekte olup yaklaşık \%30 hasta böbrek ve nörolojik sekel başta olmak üzere kalıcı hasar ile iyileşmektedirler. Akut dönemde mortalite \%1-5 oranında bildirilmektedir $(4-7,13,14)$.

Bu yazımızda Diyarbakır Gazi Yaşargil Eğitim ve Araştırma Hastanesi Çocuk Yoğun Bakım Birimimizde izlediğimiz D+HÜS hastaları ile ilgili deneyimimizi ve hastalığın klinik gidişi hakkındaki klinik verileri paylaşmayı ve klinik öngördürücüleri saptamayı amaçladık.

\section{GEREÇ VE YÖNTEM}

Geriye dönük olarak yapılan bu çalışmaya Mart 2019-Ağustos 2020 tarihleri arasında çocuk yoğun bakımda D+HÜS tanısı alan 15 çocuk hasta dahil edildi. Hemolitik üremik sendrom tanısı, öyküsünde ishal olan çocuklarda, akut böbrek hasarı ile birlikte periferik kan yaymasında \% 5 'in üzerinde parçalanmış eritrosit görülmesi, hemoglobin düşüklüğü ve başka nedenler ile açıklanamayan trombositopeni $\left(<150 \times 10^{3} / \mathrm{mm}^{3}\right)$ saptanması durumunda konuldu. Başlangıç koagülasyon parametreleri normal olan olgular çalışmaya dahil edildi. Hastaların yaş (ay), cins, vücut ağırlığı (kg), başvuru öncesi geçen süre (gün), başvuru öncesindeki yakınmaları (ishal, kanlı ishal, kusma, antibiyotik kullanımı) kayıt edildi. Olguların başvuru anındaki hidrasyon durumu, sistolik ve diyastolik kan basıncı ölçümleri, laboratuvar parametreleri [hemoglobin ( $\mathrm{g} / \mathrm{dl})$, hemotokrit (\%), beyaz kan hücresi $(/ \mathrm{L})$, trombosit $\left(x 10^{3} / \mathrm{mm}^{3}\right)$, kreatinin $(\mathrm{mg} / \mathrm{dl})$, üre $(\mathrm{mg} / \mathrm{dl})$, ürik asit $(\mathrm{mg} / \mathrm{dl})$, laktat dehidrogenaz $(\mathrm{mg} / \mathrm{dl})$, aspartat aminotransferaz (U/L), alanin aminotransferaz (U/L), amilaz $(\mathrm{U} / \mathrm{L})$, albümin $(\mathrm{g} / \mathrm{dl}), \mathrm{C} 3$ (g/L) ve $\mathrm{C} 4 \mathrm{~g} / \mathrm{L})$ ], plazma tedavisi, plazma değişimi, BYKT uygulandıysa tipi ve süresi, kan ürünü ihtiyacı olup olmadığı incelendi. Hipertansiyon, sistolik veya diyastolik kan basıncı ölçümünün yaş, cins ve boya göre ?95.p olması olarak tanımlandı (15). Olguların glomerüler filtrasyon hızları Schwartz yöntemi kullanılarak hesaplandı (16). Ayrıca olgularda böbrek dışında başka organ tutulumu varlığı, eculizumab tedavisi kullanımı ve izlemde son durumları kayıt altına alındı. Hastalardan alınan gaita örnekleri T.C. Sağlık Bakanlığı Halk Sağlığı Genel Müdürlüğü laboratuvarına gönderilerek gaita kültürü, şigatoksin PCR ve şiga toksin ELISA testleri çalışıldı. Otoimmun hastalıkların ve trombotik trombositopenik purpuranın dışlanabilmesi için olguların tümünde direk coombs ve ADAMTS13 testleri çalışıldı. Direk coombs testinin negatif olmaSI ve ADAMTS13 seviyesinin >\%10 olması durumunda olgular çalışmaya dahil edildi.

Eculizumab tedavisi uygulanan olgularda tedavi öncesinde S.pneumoniae, H.influenza ve N.meningitidis aşıları tamamlanarak 2 hafta süresince antibiyotik proflaksisi uygulandı.

Klinik gidiş için kötü öngörü faktörleri; 1.4 haftadan uzun hafta oligüri, 2. On beş günden uzun süren akut diyaliz ihtiyacı, 3. Nörolojik semptom varlığı, 4. Plazma tedavisi uygulanması, 5. Beyaz kan hücresi sayısı yüksekliği $\left(>20.000 / \mathrm{mm}^{3}\right)$ olarak belirlendi $(3,6)$.

İstatistiksel analizde kategorik veriler sayı (n) ve yüzde (\%), sayısal veriler ise aritmetik ortalama \pm standart sapma, minimum ve maksimum değerler ve ortanca şeklinde ifade edildi. Kategorik verilerin değerlendirilmesi Pearson ki-kare testi kullanılarak yapıldı. Normal dağılıma sahip sayısal verilerden oluşan bağımsız iki grubun karşılaştırılmasında Student-t, normal dağılıma sahip olmayan bağımsız iki grubun karşılaştırılmasında Mann-Whitney-U testi kullanıldı. Lojistik regresyon analizinde odds oranı (OR) \%95 güven sınırları (\%95 Cl) içinde hesaplandı. Verilerin analizi için IBM SPSS v24 (New York, ABD) programı kullanılarak, $p<0,05$ istatistiksel olarak anlamlı kabul edildi.

Çalışmanın etik kurul onayı Sağlık Bilimleri Üniversitesi İzmir Tepecik Eğitim ve Araştırma Hastanesi etik kurulundan alındı.

\section{BULGULAR}

Çalışma grubunun genel özellikleri Tablo 1'de verildi. Çalışma grubu 9 (\%60) erkek, 6 (\%40) kızdan oluşmakta olup, yaş ortalaması ortanca 18 ay olarak hesaplandı. Ortalama vücut ağırlığı $13,64 \pm 5,29$ olarak bulundu. On bir $(\% 73,3)$ olguda kan basıncı yüksekliği mevcut idi. Olguların başvuru öncesinde belirttikleri

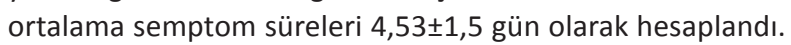


Tablo 1: Çalışma grubunun klinik ve laboratuvar özellikleri.

\begin{tabular}{|c|c|}
\hline \multicolumn{2}{|l|}{ Cins $n(\%)$} \\
\hline Erkek & $9(60)$ \\
\hline Kadın & $6(40)$ \\
\hline Yaş (ay) (ortanca) (25.-75. çeyrek) & $18,00(13-34)$ \\
\hline Vücut ağırlığı (kg) (ortıSTD)(min. - maks.) & $13,64 \pm 5,29(9,5-26,0)$ \\
\hline \multicolumn{2}{|l|}{ Kan basıncı (mmHg) } \\
\hline 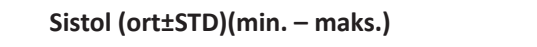 & $98,26 \pm 15,44(76-128)$ \\
\hline 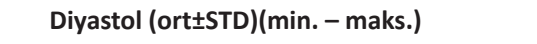 & $56,93 \pm 10,38(45-82)$ \\
\hline Hipertansiyon (+) n(\%) & $11(73,3)$ \\
\hline 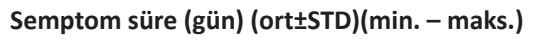 & $4,53 \pm 1,50(3-7)$ \\
\hline Antibiyotik kullanımı + n(\%) & $15(100)$ \\
\hline \multicolumn{2}{|l|}{ Kanlı ishal n(\%) } \\
\hline Var & $8(53,33)$ \\
\hline Yok & $7(46,66)$ \\
\hline \multicolumn{2}{|l|}{ Hidrasyon durumu n(\%) } \\
\hline Normal & $7(46,66)$ \\
\hline Azalmış & $2(13,33)$ \\
\hline Artmış & $6(40)$ \\
\hline Laboratuvar & 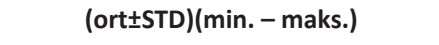 \\
\hline Hemoglobin (g/dl) & $8,18 \pm 1,81(5,60-12,40)$ \\
\hline Hemoglobin (g/dl) (min.) & $5,50 \pm 0,89(4,00-7,60)$ \\
\hline Hemotokrit (\%) & $24,78 \pm 5,15(15,80-36,50)$ \\
\hline Hemotokrit (\%) (min.) & $16,37 \pm 2,87(11,70-23,50)$ \\
\hline BKH $\left(/ \mathrm{mm}^{3}\right)$ & $16.380 \pm 6.257,16(6.700-32.930)$ \\
\hline BKH (maks.) $\left(/ \mathrm{mm}^{3}\right)$ & $22.831 \pm 9.155,87(9.460-41.280)$ \\
\hline Trombosit $\left(/ \mathrm{mm}^{3}\right)$ & $64.000 \pm 36.722,90(26.000-155.000)$ \\
\hline Trombosit (/mm³) (min.) & $43.533 \pm 25.626,06(7.000-98.000)$ \\
\hline Üre (mg/dl) & $149,65 \pm 94,19(66,00-411,50)$ \\
\hline Üre (mg/dl) (maks.) & $184,64 \pm 94,45(66,00-424,00)$ \\
\hline Kreatinin (mg/dl) & $3,12 \pm 2,53(1,11-10,86)$ \\
\hline GFH (ml/dk/1,73 m²) & $21,0 \pm 13,49(6,18-62,43)$ \\
\hline Kreatinin (mg/dl) (maks.) & $4,29 \pm 2,74(1,11-11,20)$ \\
\hline GFH (ml/dk/1,73 m²) (min.) & $15,88 \pm 13,85(5,99-62,43)$ \\
\hline Ürik asit (mg/dl) & $11,10 \pm 3,14(7,66-18,83)$ \\
\hline Ürik asit (mg/dl) (maks.) & $12,39 \pm 3,22(7,70-19,40)$ \\
\hline LDH (mg/dl) & $2.049,46 \pm 697,42(975-3.885)$ \\
\hline LDH (mg/dl) (maks.) & $2.491,06 \pm 1.196,04(975-5.443)$ \\
\hline AST (U/L) & $106,64 \pm 70,30(34,30-286,30)$ \\
\hline ALT (U/L) & $60,56 \pm 37,43(20,40-72,00)$ \\
\hline Amilaz (U/L) & $45,53 \pm 28,59(14,00-98,00)$ \\
\hline Albümin (g/dl) & $3,06 \pm 0,57(1,90-3,80)$ \\
\hline C3 (g/L) & $0,80 \pm 0,22(0,42-1,18)$ \\
\hline $\mathrm{C} 4$ (g/L) & $0,15 \pm 0,06(0,04-0,28)$ \\
\hline
\end{tabular}

Std,: Standart; Min: Minimum; Maks: Maksimum; BKH: Beyaz kan hücresi; GFH: Glomerüler filtrasyon hızı; LDH: Laktat dehidrogenaz; AST:; ALT: 
Sekiz $(\% 57,14)$ olguda kanlı ishal öyküsü olduğu görüldü. Başvuru anında yapılan hidrasyon durumu değerlendirmesinde 7 $(\% 46,66)$ olgunun hidrasyonun normal olduğu saptandı. Tanı öncesinde olguların tümünde antibiyotik tedavisi kullanım öyküsü mevcuttu.

Olguların laboratuvar parametreleri Tablo 1'de sunuldu. Bir olguda başvuru hemoglobin değeri $12,4 \mathrm{~g} / \mathrm{dl}$ olup, alınan kontrol tetkikinde 5,7 g/dl'ye düştüğü görüldü. Benzer şekilde aynı olgunun başvurusunda trombosit sayısı $155.000 / \mathrm{mm}^{3}$ olan olgunun kontrol tetkikinde bu sayının $58.000 / \mathrm{mm}^{3 \prime}$ e düştüğü saptandı. Başvuru anında bakılan beyaz kan hücresi ortalama $16.380 \pm 6.257,16 / \mathrm{mm}^{3}$ olarak hesaplandı. Tüm olguların direk coombs testi negatif ve serum ADAMTS13 seviyeleri normal sınırlar içerisinde sonuçlandı. Gaita örneklerinden altısında (\%40) şiga toksin üreten E.coli gösterildi [5 EHEC (0157:H7), 1 EAEC (O104:H4)].

İdrar çıkışı değerlendirildiğinde, $10(\% 66,7)$ olguda anüri saptanırken, sadece bir $(\% 6,7)$ olguda normal idrar çıkışı normal sınırlarda seyretti. Diğer $4(\% 26,8)$ olgu ise oligürik olarak değerlendirildi. Oligoanuri süresi ortanca 72 saat (25.-75. çeyrek: 0-190) olarak hesaplandı. Tüm çalışma grubunun \%60'ında BYKT intiyacı olup, periton diyalizi (PD) [5 $(\% 33,3)$ olgu] en sık tercih edilen BYKT yöntemi olduğu görüldü. İki $(\% 13,3)$ hastada PD ile yeterli diyaliz yapılamaması sonucu hemodiyaliz tedavisine geçildi. Nörolojik tutulumları da olan $2(\% 13,3)$ hasta invajinasyon nedeni ile abdominal cerrahi işlem gerekliliği sonrasında hemodiyafiltrasyon tedavisine geçilerek diyalize devam edildi. Böbrek yerine koyma tedavisi süresi ortalama 15,11ะ9,11 (ortanca: 11) gün olarak hesaplandı. Nörolojik tutulumu olan 2 $(\% 13,3)$ hastaya 3 seans plazma değişimi uygulanması sonrasında eculizumab tedavisi uygun dozda verildi (Tablo 2 ).

Çalışmaya dahil edilen olguların beşinde $(\% 33,3)$ böbrek dışı organ tutulumu izlendi. İki $(\% 13,3)$ olguda nörolojik tutulum mevcut olup, her ikisinde de semptom olarak bilinç değişikliği ve nöbet aktivitesi görüldü. İzlemlerinde her iki olguda mekanik ventilatör ihtiyacı gelişti. Olguların kraniyal manyetik rezonans görüntülemelerinde intrakraniyal yaygın sinyal artı̧ı ve difüzyon kısıtlılığı görüldü. Bu olguların birinde nörolojik tutuluma ek olarak kardiyak tutulum olarak distritmi ve kardiyak enzim yüksekliği, gastrointestinal tutulum olarak invajinasyon, göz tutulumu olarak retinal kanlanmada bozukluk ve görme kaybı ve pulmoner hemoraji görüldü. İkinci olguda ise nörolojik tutuluma ilave olarak invajinasyonun da eşlik ettiği saptandı. Ek olarak bir hastada HÜS'ün gastrointestinal sistem tutulumu ile ilişkilendirilen ve kan transfüzyonu gerektiren Gis kanaması görüldü. İki $(\% 13,3)$ olguda ise izlemde gerileyen transaminaz enzim düzeyi yükseklikleri gözlendi (Tablo 2).

Olgularda hastalık başlangıcında kötü öngörü faktörleri bulunması ile son durumları arasında istatistiksel açıdan anlamlı bir ilişki saptanmadı $(p>0,05)$. Fakat kötü öngörü faktörü olan 7 olgunun üçünde $(\% 42,85)$ sekel geliştiği, bu oranın kötü öngörü faktörü olmayan gruba $(\% 37,5)$ göre daha yüksek olduğu saptandı. Çalışmaya dahil edilen tüm parametrelerden hastane yatı̧ ve oligoanüri süresinin sekel gelişimi üzerine istatistiksel
Tablo 2: Hastaların klinik ve tedavi özellikleri.

\begin{tabular}{|c|c|}
\hline \multicolumn{2}{|l|}{ Oligoüri (n) (\%) } \\
\hline Var & $14(93,3)$ \\
\hline Yok & $1(6,7)$ \\
\hline \multicolumn{2}{|l|}{ Anüri (n) (\%) } \\
\hline Var & $10(66,7)$ \\
\hline Yok & $5(33,3)$ \\
\hline Oligo-anüri süre (saat) (ortanca) (25.-75. çeyrek) & $72(0-190)$ \\
\hline Ek organ tutulumu $n$ (\%) & $5(33,3)$ \\
\hline \multicolumn{2}{|l|}{ BYKT (n) (\%) } \\
\hline Var & $9(60)$ \\
\hline Yok & $6(40)$ \\
\hline \multicolumn{2}{|l|}{ BYKT tipi (n) (\%) } \\
\hline PD & $5(33,3)$ \\
\hline $\mathrm{PD} / \mathrm{HD}$ & $2(13,3)$ \\
\hline PD/HDF & $2(13,3)$ \\
\hline 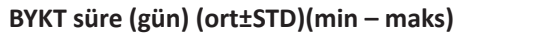 & $15,11 \pm 9,11(6-32)$ \\
\hline \multicolumn{2}{|l|}{ Plazma değişimi (n) (\%) } \\
\hline Var & $2(13,3)$ \\
\hline Yok & $13(86,7)$ \\
\hline \multicolumn{2}{|l|}{ Plazma infüzyonu (n) (\%) } \\
\hline Var & $5(33,3)$ \\
\hline Yok & $10(66,7)$ \\
\hline \multicolumn{2}{|l|}{ Eculizumab (n) (\%) } \\
\hline Var & $2(13,3)$ \\
\hline Yok & $13(86,7)$ \\
\hline \multicolumn{2}{|l|}{ Kötü öngörü faktörü (n) (\%)* } \\
\hline Var & $7(\% 46,7)$ \\
\hline Yok & $8(\% 53,3)$ \\
\hline Yatış süresi (gün) (ortanca)(25.-75. çeyrek) & $12,00(7-32)$ \\
\hline
\end{tabular}

PD: Periton diyalizi; HD: Hemodiyaliz; HDF: Hemodiyafiltrasyon;

ort: Ortalama; STD: Standart deviasyon; min: Minimum; maks: Maksimum; $* p>0.05$.

olarak anlamlı etkisi olduğu görüldü [Hastane yatı̧s süre: $O R$ : 1,28 (\%95 Cl: 0,77-0,98) ( $p=0,04)$, Oligoanüri süre: OR: 1,46 (\%95 Cl: 0,94-1) $(p=0,04)]$.

Olguların BYKT ihtiyacına göre yapılan değerlendirme Tablo 3'te verildi. Böbrek yerine koyma tedavisi yapılan olgularda kanlı ishal varlığı anlamlı olarak daha fazla olarak görüldü $(p=0,02)$. Ayrıca laboratuvar parametreleri içerisinde pik üre ve pik kreatinin değerlerinin BYKT intiyacı olmayan olgulara göre istatistiksel anlamlı olarak bir biçimde daha yüksek olduğu görüldü ( $p=0,03$, $p=0,03)$. Böbrek dışı organ tutulumu olan olguların sadece diyaliz tedavisi uygulanan olgular olduğu gözlendi $(p=0,02)$. Ayrıca böbrek yerine koyma tedavisi uygulanan olguların hastane yatış sürelerinin belirgin olarak daha uzun olduğu saptandı $(p=0,007)$. 
Tablo 3: Böbrek yerine koyma tedavisi (BYKT) alan ve almayan grupların özellikleri.

\begin{tabular}{|c|c|c|c|}
\hline & BYKT (+) n:9 (\%60) & BYKT (-) n:6 (\%40) & $p$ \\
\hline \multicolumn{4}{|l|}{ Cins n (\%) } \\
\hline Erkek & $6(39,6)$ & $3(19,8)$ & \multirow{2}{*}{$>0,05$} \\
\hline Kadın & $3(19,8)$ & $3(19,8)$ & \\
\hline Yaş (ay) (ortanca) (25.-75. çeyrek) & $16(13,5-56,5)$ & $19,5(10,75-55)$ & $>0,05$ \\
\hline Vücut ağırlığı (kg) (ortıSTD)(min. - maks.) & $13,74 \pm 5,8(9,5-26)$ & $13,5 \pm 4,9(9,5-23)$ & $>0,05$ \\
\hline 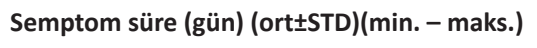 & $5 \pm 1,58(3-7)$ & $3,83 \pm 1,16(3-6)$ & $>0,05$ \\
\hline Kanlı ishal + n (\%) & $7(46,6)$ & $1(6,6)$ & 0,02 \\
\hline \multicolumn{4}{|l|}{ Hidrasyon durumu n(\%) } \\
\hline Normal & $3(19,8)$ & $4(26,4)$ & \multirow{2}{*}{$>0,05$} \\
\hline Anormal & $6(39,6)$ & $2(13,2)$ & \\
\hline Yatış süre (gün) (ortıSTD)(min. - maks.) & $24,67 \pm 12,39(9-39)$ & $7,33 \pm 3,07(4-12)$ & 0,007 \\
\hline \multicolumn{4}{|l|}{ 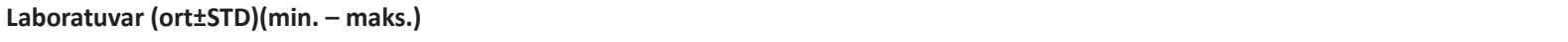 } \\
\hline Hemoglobin (g/dl) & $8,26 \pm 2,06(5,6-12,4)$ & $8,05 \pm 1,54(6,6-10,9)$ & $>0,05$ \\
\hline Hemoglobin (g/dl) (min.) & $5,6 \pm 0,93(4-7,6)$ & $5,36 \pm 0,89(4,3-6,4)$ & $>0,05$ \\
\hline Hemotokrit (\%) & $25,32 \pm 5,89(15,8-36,5)$ & $23,98 \pm 4,19(19,5-31,1)$ & $>0,05$ \\
\hline Hemotokrit (\%) (min.) & $16,77 \pm 3,07(11,7-23,5)$ & $15,76 \pm 2,7(12,5-18,5)$ & $>0,05$ \\
\hline $\mathrm{BKH}\left(\mathrm{x} 10^{3} \mathrm{U} / \mathrm{L}\right)$ & $17,99 \pm 6,8(11,71-32,93)$ & $13,95 \pm 4,86(6,7-19,78)$ & $>0,05$ \\
\hline BKH (maks.) (x1030/L) & $26,48 \pm 9,31(14,36-41,28)$ & $17,34 \pm 5,97(9,46-23,76)$ & $>0,05$ \\
\hline Trombosit $\left(\times 10^{3} / \mathrm{mm}^{3}\right)$ & $61,11 \pm 40,19(26-155)$ & $68,33 \pm 33,96(34-120)$ & $>0,05$ \\
\hline Trombosit $\left(\times 10^{3} / \mathrm{mm}^{3}\right)$ (min.) & $38,44 \pm 13,47$ (19-59) & $51,11 \pm 37,83(7-98)$ & $>0,05$ \\
\hline Üre (mg/dl) & $170,35 \pm 112,23(76,1-411,5)$ & $118,6 \pm 52,55(66-195,7)$ & $>0,05$ \\
\hline Üre (mg/dl) (maks.) & $222,554 \pm 100,3(76,2-424)$ & $127,83 \pm 49,15(66-195,7)$ & 0,03 \\
\hline Kreatinin (mg/dl) & $3,71 \pm 3,09(1,41-10,86)$ & $2,24 \pm 1,04(1,11-4,07)$ & $>0,05$ \\
\hline GFH (ml/dk/1,73 m²) & $18,05 \pm 8,93(6,18-29,82)$ & $25,42 \pm 18,52(11,08-62,43)$ & $>0,05$ \\
\hline Kreatinin (mg/dl) (maks.) & $5,45 \pm 2,82(2,44-11,2)$ & $2,55 \pm 1,53(1,11-5,44)$ & 0,03 \\
\hline GFH (ml/dk/1,73 $\left.\mathrm{m}^{2}\right)$ (min.) & $10,29 \pm 4,03(5,99-17,55)$ & $24,26 \pm 19,27(8,29-62,43)$ & 0,01 \\
\hline Ürik asit (mg/dl) & $11,59 \pm 3,81(7,66-18,83)$ & $10,36 \pm 1,82(7,7-12,45)$ & $>0,05$ \\
\hline Ürik asit (mg/dl) (maks.) & $13,4 \pm 3,52(8,55-19,4)$ & $10,89 \pm 2,14(7,7-13,3)$ & $>0,05$ \\
\hline LDH (mg/dl) & $2134,44 \pm 676,77(1633-3885)$ & $1922 \pm 772,38(975-3298)$ & $>0,05$ \\
\hline LDH (mg/dl) (maks.) & $2829,66 \pm 2353,84(1633-5443)$ & $1983,16 \pm 746,27(975-3298)$ & $>0,05$ \\
\hline AST (U/L) & $120,77 \pm 86,53(34,3-286,3)$ & $85,43 \pm 30,97(46-138)$ & $>0,05$ \\
\hline ALT (U/L) & $72,67 \pm 41,46(23-172)$ & $42,4 \pm 22,66(20,4-85)$ & $>0,05$ \\
\hline Amilaz (U/L) & $46,88 \pm 29,54(14-98)$ & $43,5 \pm 29,74(15-95)$ & $>0,05$ \\
\hline Albümin (g/dl) & $3,05 \pm 0,61(1,9-3,8)$ & $3,06 \pm 0,57(2,4-3,8)$ & $>0,05$ \\
\hline C3 (g/L) & $0,83 \pm 0,26(0,42-1,18)$ & $0,77 \pm 0,16(0,62-1,01)$ & $>0,05$ \\
\hline $\mathrm{C4}(\mathrm{g} / \mathrm{L})$ & $0,14 \pm 0,06(0,04-0,23)$ & $0,17 \pm 0,07(0,08-0,28)$ & $>0,05$ \\
\hline ERT n (\%) & $5(33)$ & $2(13,2)$ & $>0,05$ \\
\hline Ek organ tutulumu + n (\%) & $5(33)$ & $0(0)$ & 0,02 \\
\hline Sekel + n (\%) & $5(33)$ & $1(6,6)$ & $>0,05$ \\
\hline
\end{tabular}

Std,: Standart; Min: Minimum; Maks: Maksimum; BKH: Beyaz kan hücresi; GFH: Glomerüler filtrasyon hizl; LDH: Laktat dehidrogenaz; AST:Aspartat aminotransferaz; ALT:Alanin aminotransferaz ; ERT: Eritrosit transfüzyonu. 
Çalışma grubunun son durumu Tablo 4'te verildi. Ortalama izlem süresi $9,59 \pm 6,03$ ay olarak hesaplandı. Bu süreç içerisinde 9 (\%60) olgunun tamamen normale döndüğü, 3 (\%20) olguda proteinüri, 1 (\%6.6) olguda kronik böbrek hastalığı, 1 (\%6.6) olguda son dönem böbrek yetmezliği (kronik PD programında) ve 1 (\%6.6) olguda da nörolojik sekel kaldığı görüldü (Tablo 4).

Tablo 4: Olguların son durumları.

\begin{tabular}{|c|c|}
\hline $\begin{array}{l}\text { Ortalama izlem süre (ay) (ort } \pm S T D) \\
\text { (min - maks) }\end{array}$ & $9,59 \pm 6,03(0,63-18,80)$ \\
\hline \multicolumn{2}{|l|}{ Son Kontrol (n) (\%) } \\
\hline Normal & $9(60)$ \\
\hline Proteinüri & $3(20)$ \\
\hline Kronik böbrek hastalığı & $1(6,7)$ \\
\hline Son dönem böbrek yetmezliği (PD) & $1(6,7)$ \\
\hline Nörolojik sekel & $1(6,7)$ \\
\hline $\begin{array}{l}\text { Kreatinin (mg/dl) (ortanca) } \\
\text { (25. - 75. çeyrek) }\end{array}$ & $0,47(0,41-0,61)$ \\
\hline $\begin{array}{l}\text { GFH (ml/dk/1,73 m²) (ort } \pm S T D) \\
\text { (min - maks) }\end{array}$ & $91,85 \pm 41,73(11,90-203,82)$ \\
\hline
\end{tabular}

PD: Periton diyalizi; GFH: Glomerüler filtrasyon hızı,

\section{TARTIŞMA}

Çocukluk çağında az görülen fakat sonuçları itibari ile önemli bir hastalık olan D+HÜS konusunda yaptı̆ımız bu geriye dönük çalışmada olguların \%40 gibi önemli bir kısmında sekel ile iyileşme olduğunu gözlemledik. Ayrıca olguların hastanede kalış ve oligoanüri süreleri ile, sekel gelişimi arasında anlamlı bir ilişki olduğunu saptadık. Ek olarak BYKT ihtiyacı olan hastalarda daha yüksek oranda böbrek dışı organ tutulumu olduğunu saptadık. Bu durumun hastane yatış süresinin uzaması üzerinde de anlamlı etkisi olduğu kanısındayız. Klasik bilgi ile uyumlu olarak D+HÜS tanısı alan olguların böbrek fonksiyonları ve idrar çıkışlarının yakından izlenmesi gerektiğini, hastane yatıs sürelerinin ve BYKT ihtiyacının hastalığın gidişat hakkında önemli bilgiler verdiğini düşünmekteyiz.

Yukarıda da belirtildiği üzere D+HÜS çocukluk çağında sıklıkla 5 yaş altında görülmektedir (2,11,17-20). Ülkemizde 2011 yılında görülen HÜS salgını sonrasında Ekinci ve arkadaşları (21) tarafindan gerçekleştirilen çok merkezli çalışmada yaş ortalaması salgın bölgesinde 7,3 yıl ve salgın bölgesi dışında 6,7 yıl olarak hesaplanmıştır. Bizim çalışma grubumuzun ortanca yaşı literatür ile uyumlu olup 18 ay olarak hesaplandı (Tablo 1). Diyare ilişkili HÜS için cinsler arasında bir fark tanımlanmamıştır (2-8,11,1519). Çalışmamızda $9(\% 60)$ erkek hasta olup cinsler arasında anlamlı fark görülmedi. Yine benzer şekilde olguların başvurusundan önceki semptom süreleri literatür ile uyumlu olarak değerlendirildi $(2,7,18,20)$ (Tablo 1). Diyare ilişkili HÜS'de kanlı ishal sıklığı \%32,6-75 olarak bildirilmektedir $(1,11,18,21)$. Tablo 1'de görüldüğü üzere $8(\% 53,3)$ hastada kanlı ishal olduğu görüldü.

Antibiyotik kullanımı ve HÜS gelişmesi arasında olduğu düşünülen kolaylaştırıcı etki net olarak ortaya konulamamış olup konu hakkında çeşitli görüşler mevcuttur (3-5,9,12,22). Güncel olarak 2011 Almanya HÜS salgınında makrolid antibiyotik kullanımının hastalık aktivitesi üzerine etkisi olmadığı, uzun süreli E.coli taşıyıcılığını azalttı̆̆ı ve nöbet sıklığını azalttı̆̆ gösterilmiştir $(5,23,24)$. Hastalarımızın tamamında ishal nedeni ile ilk başvurdukları merkezde antibiyotik başlandığı görüldü (Tablo 1).

Çalışma grubunun başvuru anında ki ortalama beyaz kan hücresi sayısı 16.380 $\pm 6.257,16 / \mathrm{mm}^{3}$ (6.700-32.930) olarak bulundu. Bu ortalamanın daha öncesinde literatürde HÜS oluşumunu açısından risk faktörleri arasında tanımlanan beyaz kan hücresi sayısı yüksekliği ile uyumlu olduğu görüldü $(1,3,6,9,12)$. Ardissino ve arkadaşlarının (2) D+HÜS hastalarının başvuru anındaki hidrasyon durumlarının değerlendirilmesi ve sonrasında erken Sıvı tedavisinin etkinliği üzerine yaptıkları çalışmada, erken sıvı tedavisinin kısa dönemde santral sinir sistemi tutulumu, diyaliz ihtiyacı, hastane yatış süresi ve ölüm oranında ve ayrıca uzun dönemde sekel kalımı üzerine azaltıcı yönde önemli katkısının olduğunu göstermişlerdir. Bizim çalışmamızda $13(\% 86,66)$ hastada hidrasyon durumunun normal veya artmış olduğu görüldü. Fakat yapılan analizlerde kısa ve uzun dönemde hastalığın seyri üzerine anlamlı bir etkisi bulunamadı.

Diyare ilişkili HÜS'lü olgularda etkenin saptanması için yapılan gaita incelemelerinde başarı oranları çok değişkenlik göstermektedir $(1,8,18,20,21,25)$. Bu durum olgularında tanı öncesinde antibiyotik tedavisi kullanmaları ve lojistik nedenler ile gaita örneğinin hızlıca uygun laboratuvara yönlendirilememesi ile açıklanmaya çalışımaktadır. Hastalarımızın tamamında gaita analizi gönderilmiş olmasına rağmen sadece $6(\% 40)$ örnekte şiga toksin üreten E.coli gösterilebildi [5 EHEC (0157:H7), 1 EAEC (O104:H4)]. Bizde de benzer şekilde olan bu durumu tüm hastalarımızın başvuru öncesinde antibiyotik tedavisi kullanmış olmaları ve merkez laboratuvara olan uzaklığımız ile ilişkili olduğunu düşünmekteyiz.

Diyare ilişkili HÜS klinik izleminde \%90'lara varan oranlarda oligoanüri bildirilmektedir $(7,11,18,20,21,26,27)$. Oligoanüri süreleri Ekinci ve arkadaşları tarafindan 10,43 gün, Micheletti ve arkadaşları tarafindan ise $\% 77$ olguda beş günden fazla olarak bildirilmiştir (7,21). Bizim çalışmamızda olguların \%93,3'ünde oligüri, \%66,7'sinde ise anüri izlendi. Ortanca oligoanüri süresi 72 saat (25.-75. çeyrek: 0-190) olarak hesaplandı. Çalışma grubunda başlangıçta oligoanüri sık olarak görülmekle birlikte ortanca 72 saat gibi bir sürede normal idrar çıkışı gözlenmesi, uygun hidrasyon tedavisinin önemini vurgulamaktadır (Tablo 2). Literatür ile uyumlu olarak hastalarımızın \%60'ında BYKT ihtiyacı gözlendi $(7,11,18,20,21,26,27)$. Diyare ilişkili HÜS hastalarında ortalama BYKT tedavisi süreleri 10-18,5 gün aralığında olduğu bildirilmektedir $(1,7,8,17,18,21)$. Bizim çalışmamızda da ortalama BYKT süresi literatür ile uyumlu olup, 15,11£9,11 gün olarak hesaplandı. Ciddi nörolojik tutulumu ve/veya ciddi hastalık seyri göstermekte olan olgular için özelikle eculizimab tedavisine ulaşana kadar plazma tedavisinin kendisi veya plazma değiştirici tedaviler önerilse de, bu tedavilerin D+HÜS'de hastalık ilişkili sekel gelişiminde önemli bir etkisinin olmadığı düşündüren yayınlar da mevcuttur $(3-6,12,23,28)$. Plazma değişimi tedavisi uygulanması sonrasında tedavilerine eculizumab 
ile devam ettiğimiz ciddi nörolojik tutulumu olan 2 olgudan birisinde nörolojik sekel kalmıştır (Tablo 2,4).

Şiga toksinin endotel hücrelerine direk hasarına ek olarak D+HÜS fizyopatolojisinde kompleman sistemininde de aracılık ettiği bilinmektedir. Bu nedenle kompleman C5 monoklonal antikoru olan eculizumabın tedavide etkili olabileceği düşünülmektedir $(3,5,6,29,30)$. Lapeyraque ve arkadaşlarının nörolojik tutulumu olan bir hastada eculizumab tedavisini erken dönemde başarı ile uygulamasının ardından D+HÜS olgularında bu ajanın kullanımı artmıştır (31). Fakat yapılan çalışmalarda sonuçlar birbiri ile çelişmektedir $(18,23,25,28,32)$. Fadi ve arkadaşları ve Bagga ve arkadaşları bu tedavinin ciddi nörolojik tutulumu olan ve/veya ciddi hastalık seyri gösteren hastalarda kullanılmasını önermektedirler $(12,29)$. Bizim çalışma grubumuzda 2 nörolojik tutulumu olan olguya ilk 7 gün içerisinde eculizumab tedavisi uygulandı (Tablo 2). Bu olgulardan ilkinde nörolojik tutulumda belirgin gerileme gözlemlenirken diğer organ tutulumlarının ortadan kalktı̆̆ görüldü. Diğer olguda ise nörolojik ve diğer organ tutulumlarının tamamen gerilediği gözlemlendi. Biz de eculizumab tedavisinin nörolojik ve/veya ciddi hastalığı olan hastalarda erken dönemde kullanılması gerektiğini düşünmekteyiz.

Klinik gidiş için kötü öngörü kriterleri olarak; 1.4 haftadan uzun süren oligüri, 2. Onbeş günden uzun süren akut diyaliz ihtiyacı, 3. Nörolojik semptom varlığı, 4. Plazma tedavisi uygulanması, 5. Beyaz kan hücresi yüksekliği $\left(>20.000 / \mathrm{mm}^{3}\right)$ tanımlanmıştır $(3,6)$. Çalışma grubumuzun $\% 46,7$ 'si bu faktörlerden en az birini bulundurmasına rağmen, bu faktörlerin hastalığın akut ve uzun dönem sonlanımı üzerine etkisi gösterilemedi. Buna rağmen oligoanüri varlığı ve hastane yatı̧ süresi ile sekel gelişimi arasında ilişki olduğu görüldü [Hastane yatı̧s süre: OR: 1,28 (\%95 Cl: 0,77-0,98) ( $p=0,04)$, Oligoanüri süre: OR: 1,46 (\%95 $C l: 0,94-1)(p=0,04)]$. Böbrek yerine koyma tedavisi alan olguların almayan olgulara göre hastane daha uzun süre kaldıkları gösterilerek ( $p=0,007)$ (Tablo 3), BYKT'nin hastane yatı̧ süresini uzatarak dolaylı yoldan beklendiği gibi sekel gelişimi açısından risk faktörü olduğu düşünüldü. Ağbaş ve arkadaşları (18) BYKT alan ve almayan hastalar arasında böbrek dışı organ tutulumu açısından fark gösterememişlerdir. Çalışmamızda ise böbrek dışı organ tutulumu olan hastaların tamamı BYKT alan hastalardan oluşmaktadır $(p=0,02)$ (Tablo 3). Bu durum yukarıda tanımlanan kötü öngörü kriterleri içerisinde BYKT'ne ihtiyaç duyan hastalarda önemli bir yer tutuğunu vurgulamaktadır.

Hastaların \%70'i tam olarak iyileşmekte olup yaklaşık \%30 hasta ise böbrek ve nörolojik sekel başta olmak üzere kalıcı hasar ile iyileşmektedirler. Çalışma grubumuzda da benzer olarak \%60 oranında tam iyileşme olduğu, 3 (\%20) olguda proteinüri, 1 $(\% 6,6)$ olguda kronik böbrek hastalığı, $1(\% 6,6)$ olguda son dönem böbrek yetmezliği (kronik PD programı) ve $1(\% 6,6)$ olguda da nörolojik sekel kaldığı gözlendi. Akut dönemde mortalite \%1-5 oranında bildirilmekte olup çalışmamızda hasta kaybı görülmedi $(4-7,13,14,18,21)$.

Diyare ilişkili HÜS ve atipik HÜS benzer klinik ile başvurabilmektedir. McCoy ve arkadaşları (10) 10 yaşında bir olguda şiga ilişkili HÜS ve kompleman bozukluğu göstermişlerdir. Sonrasında literatüre bu şekilde klinik başlangıç olabileceği yönünde yeni bilgiler eklenmiştir
$(3,29,33)$. Bizde çalışma grubumuzda nörolojik tutulumu da olan iki ciddi klinik gidişli olgumuzda kompleman sistemi anormalliği açısından genetik tetkikleri yollanarak sonuçları beklenmekteyiz.

Çalışmamızın çeşitli kısıtlılıkları bulunmaktadır. Bunlardan en belirginleri çalışmanın geriye dönük, tek merkezli ve görece küçük çalışma grubu ile gerçekleştirilmiş olmasıdır. Ayrıca hastaların son durumları ortalama 10 aylık izlem süresini kapsamaktadır. Bu sebepler ile çocuklarda D+HÜS hakkında genel çıkarımlar yapmanın doğru olmayacağını, ileriye dönük, çok merkezli ve uzun süreli gözlem içeren çalışmaların yapılmasının büyük önem arz ettiğini düşünmekteyiz.

Sonuç olarak, D+HÜS çocukluk çağında nadir görülmesine rağmen önemli oranda morbidite ve mortalite sebebi olması nedeni ile önem arz etmektedir. Bu hastalığın daha iyi tanınarak yönetiminin geliştirilmesi ile bu kötü sonuçların azaltılabilmesi için daha çok klinik çalışmaya ihtiyaç olduğunu düşünmekteyiz.

Etik Komite Onayı: : Bu çalışma için etik kurul onayı Sağıık Bilimleri Üniversitesi İzmir Tepecik Eğitim ve Araşttrma Hastanesi Etik Kurulu'ndan alınmıştır (Tarih: 23.12.2020, no: 2020/14-61).

Hakem Değerlendirmesi: Dış bağımsız.

Yazar Katkıları: Çalışma Konsepti/Tasarım- C.A., M.K.; Veri ToplamaM.N.T., A.T.; Veri Analizi/Yorumlama- C.A.; Yazı Taslağı- C.A.; İçeriğin Eleştirel İncelemesi- M.K., M.N.T., A.T.; Son Onay ve Sorumluluk- C.A., M.N.T., A.T., M.K.

Çıkar Çatışması: Yazarlar çıkar çatş̧ması beyan etmemişlerdir.

Finansal Destek: Yazarlar finansal destek beyan etmemişlerdir.

Ethics Committee Approval: This study was approved by Health Sciences University Tepecik Education And Research Hospital Ethics Committee (Date: 23.12.2020, No: 2020/14-61).

Peer Review: Externally peer-reviewed.

Author Contributions: Conception/Design of Study-C.A., M.K.; Data Acquisition- M.N.T., A.T.; Data Analysis/Interpretation-C.A.; Drafting Manuscript- C.A.; Critical Revision of Manuscript- M.K., M.N.T., A.T.; Final Approval and Accountability- C.A., M.N.T., A.T., M.K.

Conflict of Interest: Authors declared no conflict of interest.

Financial Disclosure: Authors declared no financial support.

\section{KAYNAKLAR/REFERENCES}

1. Schifferli A, von Vigier RO, Fontana M, Sparta G, Schmid H, Bianchetti MG, et al. Hemolytic-uremic syndrome in Switzerland: a nationwide surveillance 1997-2003. Eur J Pediatr 2010;169(5):591598. doi:10.1007/s00431-009-1079-9.

2. Ardissino G, Tel F, Possenti I, Testa S, Consonni D, Paglialonga F, et al. Early volume expansion and outcomes of hemolytic uremic syndrome. Pediatrics 2016;137(1). doi:10.1542/peds.2015-2153.

3. Fakhouri F, Zuber J, Frémeaux-Bacchi V, Loirat C. Haemolytic uraemic syndrome. Lancet 2017;390(10095):681-696. doi:10.1016/ S0140-6736(17)30062-4. 
4. Walsh PR, Johnson S. Treatment and management of children with haemolytic uraemic syndrome. Arch Dis Child 2018;103(3):285291. doi:10.1136/archdischild-2016-311377.

5. Cody EM, Dixon BP. Hemolytic uremic syndrome. Pediatr Clin North Am 2019;66(1):235-246. doi:10.1016/j.pcl.2018.09.011.

6. Keir LS. Shiga toxin associated hemolytic uremic syndrome. Hematol Oncol Clin North Am 2015;29(3):525-539. doi:10.1016/j. hoc.2015.01.007.

7. Micheletti MV, Lavoratti G, Materassi M, Pela I. Hemolytic uremic syndrome: epidemiological and clinical features of a pediatric population in Tuscany. Kidney Blood Press Res 2010;33(5):399404. doi:10.1159/000320385.

8. Balgradean M, Croitoru A, Leibovitz E. An outbreak of hemolytic uremic syndrome in southern Romania during 2015-2016: Epidemiologic, clinical, laboratory, microbiologic, therapeutic and outcome characteristics. Pediatr Neonatol 2019;60(1):87-94. doi:10.1016/j.pedneo.2018.04.011.

9. Scheiring J, Andreoli SP, ZimmerhackI LB. Treatment and outcome of Shiga-toxin-associated hemolytic uremic syndrome (HUS). Pediatr Nephrol Berl Ger 2008;23(10):1749-1760. doi:10.1007/ s00467-008-0935-6.

10. McCoy N, Weaver DJ. Hemolytic uremic syndrome with simultaneous Shiga toxin producing Escherichia coli and complement abnormalities. BMC Pediatr 2014;14:278. doi:10.1186/1471-2431-14-278.

11. Falup-Pecurariu O, Lixandru RI, Cojocaru E, Csutak K, Monescu V, Muhsen $\mathrm{K}$, et al. Shiga toxin producing Escherichia coli-associated diarrhea and hemolytic uremic syndrome in young children in Romania. Gut Pathog 2019;11:46. doi:10.1186/s13099-019-0327-4.

12. Bagga $A$, Khandelwal $P$, Mishra K, Thergaonkar R, Vasudevan $A$, Sharma J, et al. Hemolytic uremic syndrome in a developing country: Consensus guidelines. Pediatr Nephrol 2019;34(8):14651482. doi:10.1007/s00467-019-04233-7.

13. Garg AX, Suri RS, Barrowman N, Rehman F, Matsell D, RosasArellano MP, et al. Long-term renal prognosis of diarrheaassociated hemolytic uremic syndrome: a systematic review, metaanalysis, and meta-regression. JAMA 2003;290(10):1360-1370. doi:10.1001/jama.290.10.1360.

14. Spinale JM, Ruebner RL, Copelovitch L, Kaplan BS. Long-term outcomes of Shiga toxin hemolytic uremic syndrome. Pediatr Nephrol 2013;28(11):2097-2105. doi:10.1007/s00467-012-2383-6.

15. Flynn JT, Kaelber DC, Baker-Smith CM, Blowey D, Carroll AE, Daniels SR, et al; Subcommittee on screening and management of high blood pressure in children. Clinical practice guideline for screening and management of high blood pressure in Children and Adolescents. Pediatrics 2017;140(3):e20171904. doi:10.1542/ peds.2018-1739.

16. Schwartz GJ, Muñoz A, Schneider MF, Mak RH, Kaskel F, Warady BA, et al. New equations to estimate GFR in children with CKD. J Am Soc Nephrol 2009;20(3):629-637. doi:10.1681/ASN.2008030287.

17. Al-Eisa A, Al-Hajeri M. Hemolytic uremic syndrome in Kuwaiti Arab children. Pediatr Nephrol 2001;16(12):1093-1098. doi:10.1007/ s004670100036.

18. Ağbaş A, Göknar N, Akıncı N, Yıldırım ZY, Taşdemir M, Benzer M, et al. Outbreak of Shiga toxin-producing Escherichia-coli-associated hemolytic uremic syndrome in Istanbul in 2015: outcome and experience with eculizumab. Pediatr Nephrol 2018;33(12):23712381. doi:10.1007/s00467-018-4033-0.
19. Kemper MJ. Outbreak of hemolytic uremic syndrome caused by E. coli 0104:H4 in Germany: a pediatric perspective. Pediatr Nephrol 2012;27(2):161-164. doi:10.1007/s00467-011-2067-7.

20. Alconcher LF, Coccia PA, Suarez ADC, Monteverde ML, Gutierrez MGPY, Carlopio PM, et al. Hyponatremia: a new predictor of mortality in patients with Shiga toxin-producing Escherichia coli hemolytic uremic syndrome. Pediatr Nephrol 2018;33(10):17911798. doi:10.1007/s00467-018-3991-6.

21. Ekinci Z, Candan C, Alpay H, Canpolat N, Akyüz SG, Gündüz Z, et al. Hemolytic uremic syndrome outbreak in Turkey in 2011. Turk J Pediatr 2013;55(3):246-252.

22. Freedman SB, Xie J, Neufeld MS, Hamilton WL, Hartling L, Tarr PI, et al. Shiga toxin-producing Escherichia coli infection, antibiotics, and risk of developing hemolytic uremic syndrome: A meta-analysis. Clin Infect Dis 2016;62(10):1251-1258. doi:10.1093/cid/ciw099.

23. Menne J, Nitschke M, Stingele R, Abu-Tair M, Beneke J, Bramstedt $\mathrm{J}$, et al. Validation of treatment strategies for enterohaemorrhagic Escherichia coli 0104:H4 induced haemolytic uraemic syndrome: case-control study. BMJ 2012;345:e4565. doi:10.1136/bmj.e4565.

24. Nitschke M, Sayk F, Härtel C, Roseland RT, Hauswaldt S, Steinhoff J, et al. Association between azithromycin therapy and duration of bacterial shedding among patients with Shiga toxinproducing enteroaggregative Escherichia coli O104:H4. JAMA 2012;307(10):1046-1052. doi:10.1001/jama.2012.264.

25. Şahin S, Özdoğan EB, Kaya G, Özgün N, Cansu A, Kalyoncu M, et al. Neurological involvement in pediatric hemolytic uremic syndrome: A symptom-oriented analysis. Neuropediatrics 2017;48(5):363370. doi:10.1055/s-0037-1603643.

26. Zhao S-A, Ning B-T, Mao J-H. Clinical characteristics of children with hemolytic uremic syndrome in Hangzhou, China. World J Pediatr 2017;13(2):183-185. doi:10.1007/s12519-017-0021-x.

27. Dotis J, Violaki A, Kotsiou M. Hemolytic uremic syndrome in a pediatric intensive care unit: a 5-year experience. Turk J Pediatr 2011;53(2):237-240.

28. Kielstein JT, Beutel G, Fleig S, Steinhoff J, Meyer TN, Hafer C, et al. Best supportive care and therapeutic plasma exchange with or without eculizumab in Shiga-toxin-producing E. coli O104:H4 induced haemolytic-uraemic syndrome: an analysis of the German STEC-HUS registry. Nephrol Dial Transplant 2012;27(10):38073815. doi:10.1093/ndt/gfs394.

29. Fakhouri F, Loirat C. Anticomplement treatment in atypical and typical hemolytic uremic syndrome. Semin Hematol 2018;55(3):150-158. doi:10.1053/j.seminhematol.2018.04.009.

30. Brady TM, Pruette C, Loeffler LF, Weidemann D, Strouse JJ, Gavriilaki E, et al. Typical HUS: Evidence of acute phase complement activation from a daycare outbreak. J Clin Exp Nephrol 2016;1(2). doi:10.21767/2472-5056.100011.

31. Lapeyraque A-L, Malina M, Fremeaux-Bacchi V, Boppel T, Kirschfink $M$, Oualha $M$, et al. Eculizumab in severe Shiga-toxin-associated HUS. N Engl J Med 2011;364(26):2561-2563. doi:10.1056/NEJMc1100859

32. Pape L, Hartmann H, Bange FC, Suerbaum S, Bueltmann E, AhlenstielGrunow T. Eculizumab in typical hemolytic uremic syndrome (HUS) with neurological involvement. Medicine (Baltimore) 2015;94(24):e1000. doi:10.1097/MD.0000000000001000.

33. Caillaud C, Zaloszyc A, Licht C, Pichault V, Frémeaux-Bacchi V, Fischbach M. CFH gene mutation in a case of Shiga toxin-associated hemolytic uremic syndrome (STEC-HUS). Pediatr Nephrol 2016;31(1):157-161. doi:10.1007/s00467-015-3207-2. 